\title{
A CREATIVE APPROACH TO A LITERARY WORK IN THE SYSTEM OF PROBLEM-BASED TEACHING
}

\author{
Marinko Lazzarich, Ph.D. \\ Faculty of Teacher Education \\ University of Rijeka (Croatia) \\ e-mail: mlazzari@inet.hr
}

\begin{abstract}
The main aim of required reading in schools is to educate the reading audience who is capable of aesthetic communicating with a literary work. Supposing that the freedom of choice substantially defines pupil relationship towards required reading, the author reflects upon the effectiveness of planning and realization of the current curriculum. As for the system of required reading in the Croatian language, interpretative approaches based on the principles of contemporariness and comparativeness are applicable in both high school and vocational school curricula. The topical hit The Museum of Innocence written by Turkish Nobel prize-winner Orhan Pamuk becomes a template for examining the possibility of the challenging combination of optional reading and system of problem-based teaching. Aimed at enhancing young readers' analytic competences, the paper provides a model of a methodical interpretation of the novel in literature teaching in the fourth grade of secondary school. Contemporary system of problem-based teaching enables a creative approach to a literary work, regarding pupils as subjects who develop their creativity and ability of critical thinking.Key words: reading culture, required reading, problembased teaching, literary communication, principle of contemporariness, Orhan Pamuk, The Museum of Innocence
\end{abstract}

\section{Introduction}

Reading is the third link in the communication triad (Lotman, 2001) consisting of a writer, a work and a reader. It is a silent activity whose social-cultural role is to transfer knowledge and messages contained in books as well as a complex process including reflective, emotional, fantastic and creative work. It is the oldest form of cultural activity because it has the power of overcoming temporal and spatial limits contributing thus to connection between humans. It has been long since a book was regarded as a phenomenon of mass communication since the occurrence of new media significantly changes its position in society, and therefore reading is becoming a mere echo of the market (Plevnik, 2006). A reading culture is being shaped by a number of individually and socially determined factors that, among other things, also arise from a cultural tradition of a social environment and thus make the status of a book inseparable from the overall value system of a single society. Reading in childhood and adolescence 
is of crucial importance for an individual's level of reading culture in later life since we are talking about a multiple complex activity. As young people's interests have changed in the last few decades, scientists fear that the Internet would overpower literature completely. Love of books is gained in a family home, while school further develops reading culture systematically within mother tongue teaching. Following the example of their European colleagues, our methodologists point out that required reading is a component part of literature teaching during the overall schooling. As for primary school, pupils gain the awareness of reading and are introduced to the best accomplishments of national literature and works of world classics, while in secondary school they upgrade artistic contents with literary-scientific cognizance. Encouraging pupils for complete and permanent reading represents a main problem of mother tongue teaching as well as a large challenge for methodologists to discover new possibilities of empowering the school communication triad.

\section{Problem of required reading reception}

During the process of literary maturation, young readers often lose their interest in literature. Pupils' attitudes towards required reading as a crime and Dostojevski as $a$ punishment can make us laugh or make us sad, but this must not leave the designers of mother tongue curricula indifferent. By determining compulsory titles, school creates discomfort and repulsive attitudes towards reading, and therefore the adjustment of teaching methods poses itself as a logical choice to solve this problem ((Lazzarich, 2001, 2004). While the system of required reading in primary school has been changed and supplemented by new titles on several occasions, in secondary school there was no such change for years. Linguistically incomprehensible works of the older Croatian literature generate a negative attitude of secondary school pupils towards required reading and, what is more, the interpretation of titles by a chronological-historical order and the choice of books that have not been revised for years result in a considerable number of major works that have not been read for years ${ }^{1}$. Young readers' habits have largely changed in the last two decades being at the same time a reason for both poorer oral and written expression and poorer young person's intellectual development. The lack of systematic research on readership rating for required reading among secondary school population brings into question the rhetoric of the relevant ministry concerning required reading as a component part of the Croatian language curriculum which all the pupils in Croatia are obliged to read. Pupils should become aware of the importance of required reading and here the teacher's autonomy, regarding the choice of literary works, is of great importance because every professor knows their pupils best. Accordingly, teachers are also familiar with the motivational procedures aimed at encouraging literary communication (Vladilo, 2002). The cognition on mass media influence on the choice of

\footnotetext{
1 The formalist approach of presenting literary science causes numerous uncertainties in teaching practice: pupils reproduct syntagms that are unaware of, such as "a poet of wooden Russia" or "Croatian Andersen", know that hexameter is "a verse with 6 metrical units" and that Marulić is "the father of Croatian literature", but they do not understand why they must read the Iliad and the older Croatian literature. As an example, the Italian education system has provided secondary pupils with an interesting approach to historical literary texts in the form of linguistic adjustment.
} 
books and tendency of youth towards reading popular literature can be used in order to develop reading culture ${ }^{2}$. Although literature teaching implies specific national characteristics, we should not ignore the experiences of world and European education systems, and their positive approaches to required reading which can be applied in the Croatian education system as well ${ }^{3}$. The accelerated development of technology and the occurrence of new media call for a different approach towards the interpretation of required reading. In this connection, a project called e-lektira (e-required reading) might prove to be a successful solution as a part of the programme aimed at informing the Croatian school system. However, it is important to win pupils over in favour of reading and not allow for books to lose a battle against Facebook beforehand. The titles of contemporary writers and hits of unquestionable literary values would certainly draw pupils closer to books, stimulate readers' interest and reduce the disproportion between life and school. Furthermore, the approach to the selected works should not be limited to a canonical text interpretation because a classical analysis, along with battered literarytheoretical set of instruments, additionally emphasises the reproductive character of teaching. Therefore, literary communication should be freshened up with various forms of interpretation and, in this context, the problem-creative system suggests itself as a right choice. Teaching reading aimed at the development of critical thinking should be the basic justification for reqired reading and its reading, while pupils should be introduced to topical texts and develop the abilities needed for text evaluation.

\section{From experience to creative knowledge}

Contemporary literature teaching methodology recognises the literary-scientific methods that, with regard to artistic text interpretation, possess appropriate scientific implementation and verified methodological reliability. An experience is an individual category since it belongs to a person inside of whom it occurs. The characteristic of experiences has an important role in accepting and interpreting the contents of learning

\footnotetext{
${ }^{2}$ Marlena Plavšić and Marko Ljubešić have tried to investigate what and how often today's youth read at their leisure, what their favourite authors are and what criterion they use for selecting books. The research was conducted on a population aged between 14 and 28 years in ten Croatian libraries in the Istria and Primorje-Gorski kotar County during summer holidays in 2009. The results confirmed the authors' null hypothesis implying that today's young readers most likely choose works of popular literature (Harry Potter, Twilight and Lord of the Rings) and that much-vaunted writers in media, such as J. K. Rowling and R. L. Stine, are also the favourite authors of young generations. As for the quantity of the read books, the results do not significantly differ from the ones obtained by Dijana Sabolović-Krajina twenty years ago. The need for a book and relation to reading is not only the problem of the Croatian school system but of the overall cultural politics of our society.

${ }^{3}$ The USA school system is rather liberal and inclined to innovation in teaching as is the case in mother tongue teaching as well. There are no standard curricula in any of the 50 states and the role of the coordinator for curriculum design is taken over by the Deparment for Education. The teacher selects titles according to pupils' individual preferences, respecting their choice, and does not insist on compulsory reading. Most European countries follow the same practice with no required reading lists, putting emphasis on curriculum individualization where each pupil looks after their own interests and enjoys the support of their teacher. In German schools pupils mostly read German literature, while in Spain there are lists of recommended titles where literature teachers select the works they would devote their attention to during the school year.
} 
because positive experiences can improve their acquisition. The reception of a certain template is particularly important regarding the art of written word because a literary work arouses an aesthetic experience in a recipient. Literature teaching methodology is not oriented to a group but an individual and there is a present awareness that every pupil is autonomous in their experience of a literary work. By using an individualised approach aimed at the development of literary communication, one can encourage operative and creative knowledge that occurs by activating the most complex intellectual functions. Creative activity becomes prominent in the reconstruction of different levels of knowledge while solving a problem, and therefore creative knowledge reveals itself in new problem situations. The problem creation methodical system affirms learning by solving problems what at the same time increases motivation for work and intensifies the level of knowledge acquisition. In this connection, the centre of the teaching process becomes a problem that pupils solve individually, gaining thus new cognisance with the assistance of the teacher (Bežen, 2008). As a literary problem is seen as an ambiguous phenomenon based on complex operations, i.e. reflective, emotional and fantastic, what becomes prominent in its solving is a recipient's subjective point of view. Therefore, a solution to the problem does not need to be unambiguous since every pupil makes efforts to solve it in their own way (Rosandić, 2005). Here, the multiple layers of problem-based teaching needs to be pointed out, particularly its gnoseologic, psychological, and pedagogical-didactic dimension. As the gnoseologic dimension encompasses the mental operations of the process of cognition, it is not possible to discover the poetic code of artistic text without its appreciation. Along with reflective activity, the psychological dimension also encompasses a motivational aspect, i.e. observation of a phenomenon and personal identification with it, while the didactic dimension refers to the educational effects of problem solving. In order to be shaped in a problem based way, a teaching content needs to fulfil certain conditions. In the first place, it needs to meet the criterion of information-content contradiction and novelty, and the criterion of motivational value. It is a matter of the dynamic situation of starting from an initial uncertainty (problem question) towards clearness (problem solving) during which a complex process develops, i.e. restructuring earlier cognisance and structural completing of a problem situation (Gajić, 2004). Based on the familiar elements in a problem situation, a possible goal is anticipated and ways leading to its realisation are considered.As for the system of required reading in the Croatian language, interpretative approaches based on the principles of contemporariness and comparativeness are applicable in both high school and vocational school curricula. The newest Orhan Pamuk's novel The Museum of Innocence meets all the criteria of the problem-based methodical teaching system. The current linguistic-methodical template of the Turkish Nobel-prize winner will serve as an example to investigate the range of a free choice of requested reading titles and discuss the encouraging possibilities of applying the problem-based approach in enhancing literary communication of pupils attending the fourth grade of secondary school. 


\section{Principle of contemporariness in selection of required reading titles}

The Museum of Innocence (Masumiyet Müzesi) written by Orhan Pamuk ${ }^{4}$ is a love novel as well as an emotional dedication to Istanbul. The novel is interesting because it refers to social conditions in Turkey while at the same time and in a creative way it changes the literary shape of a love novel. Therefore, we can conceive it as an avantguarde postmodern alteration of the traditional genre. The rich poetic garden of The Museum of Innocence offers numerous possibilities of reading, especially in the context of school interpretation with regard to the subjects topical level as well as the level of expression, style and composition: from the problems and controversies popular / aesthetic and low / high in literature, within the theme of love relationship and erotica, towards the manneristic moves in postmodern prose. The multi-layered text structure provides various approaches to interpretation.

\section{Novel interpretation}

As for the plot, we follow an intriguing story happening in Istanbul in 1975. It is about Kemal Basmac1, a thirty year old man coming from a rich family of manufacturers, and his girlfriend Sibel, a pro-West inclined girl coming from a respected upper-class family. In the 1970s, the upper-class initiated the violation of the taboo on premarital relationships and "innocence". The encounter with beautiful Füsun changes Kemal's world fundamentally: initial flirtation turns into the avalanche of emotions resulting in Kemal's breaking up with his fiancée, thus violating the well-established code of conduct of a conservative society. A tragic end of the love story completely demoralises the protagonist, inspiring in him a desire to preserve the past in the shape of a museum of memories. The imaginary quality of the museum is comparable to the reality of the book - the unusual museum becomes a map of social rituals and customs as well as an autograph book of broken love. While interpreting Pamuk's novel, the teacher would encompass the following elements: genre, topic, place and time, character characterisation, style (affiliation to stylistic formation), postmodern elements of the erotic theme, main problems of the work, and value judgement. The multi-layered expression of Pamuk's communicative prose breaks the receptive barrier put in front of the reader by a modern novel. The problems of a girl's status and passion in a conservative society where premarital relationships between partners represent a taboo serves as Orhan Pamuk's starting point: innocence is important for every girl in Turkey regardless of modern and European views. As for the spatial and temporal location, The Museum of Innocence includes the characteristics of a "classical" novel - the emotional painting of the city's sites transcends into a specific greeting card of Istanbul in the 1970s, while the social aspect remains in the background. Although the emphasis is laid on the analysis of a relationship between a man and a woman, the work is not fully limited by the term love novel. With regard to interpretation, a specific inter-relation between classical and modern can be followed in Pamuk's prose: despite the love topic,

\footnotetext{
${ }^{4}$ Turkish writer Orhan Pamuk (1952) has won the 2006 Nobel Prize in Literature. His overall creative opus is imbued with thematizing of human desolation caused by the loss of identity as a consequence of the conflict between Islam and European values.
} 
the writer does not aim for a realistic heart novel because he would thus interpret a rather narrow temporal context. On the contrary, his intention was to create an ambiguous work which would at the same time provide a reflection of both the reality and epochs that follow. Describing the world of the new rich in his novel, Pamuk assesses the absurdity of the social phenomena that represent the basic values of the petite bourgeoisie. He shapes the representatives of a primitive world in which the conformism of the petite bourgeoisie prevails, expressing his tendency towards psychological character characterisation. The novel composition is carefully constructed and nothing is left to chance: events are being retold in first person from a past perspective (vision par derriére), with a time lag of 20 years, by which the author nostalgically suggests that "the exhibits" in the book remind him of better times. The text structure ensures various forms of reading and confirms the genre and multi layers of the novel, while the presence of two narrators provides the comparison between the narrative perspectives. In a specific way, Pamuk introduces postmodern elements in the body of the text which is evident in a ludistic playing with the reader's horizon of expectations, breaking the linear course of narration and pronounced automatic referencing. The intentional re-arrangement of the plot episodes refers to a carefully planned compositional scheme while by engaging a metatextual play, the writer talks about his own poetics of creation. It is the matter of a prose cocktail ranging from mimetic prose with a condensed plot, over a psychological novel on the track of the stream of consciousness, to playing with a trivial discourse and trash. As for the multilayered Pamuk's writing, highly aesthetic digressions are being fused with a low trivial style that is also reflected in the popular elements: the determination of play in The Museum of Innocence refers to its role inside a culture and the most prominent domain where it survives in its primary form, i.e. sports. Therefore, the emphasis should be put on the influence of pop culture in which a tragically pathetic outcome in the style of an American melodrama makes sense. The exchange between low and high in Pamuk's narration is one way of reinterpreting the current problems of today's literature and its consumerism as well as the affirmation implying that funny does not need to be trivial at the same time the definition of low and high in literature can be explained by different examples in both content and style: by playing with the horizon of expectations, Pamuk deliberately places the "low" content and style at the same level as the "high" one. This ambivalence is suggested even in the title where the author joins together two lexemes that seem incompatible at first sight - museum (cultural, sublime) and innocence (profane, trivial).

In this love novel we observe romantic and manneristic elements at the level of plot, character characterisation and emotional tension that prevails between the protagonists. A sophisticated flair for style is most prominent in an intoxicating romantic amalgam: a large number of the plot lines reveal, in accordance with the poetics of romanticism, a dark side of love connected with the phenomenology of outer violence and punishment in terms of adultery and suicide. The intertextual evocation of romantic motives, strong emotion and Goethe's love triangle represent a citational dedication to romanticism and a literary bridge towards the most emotional period in literary history. By using a ludistic manner and playing with the world of literary works, Pamuk enriches his fiction with actual elements, while, by playing with the recipient's horizon of expectations he becomes a character in the story himself. However the story also includes the mirror effect because the reader becomes drawn into the plot by the offered 
admission ticket and invitation to "the museum", while the author uses the switch between narrators to experiment with narrative patterns. By removing the borders between real and unreal Pamuk insists on doing away with time, the book becomes a museum and the reader becomes a visitor who walks through it, by viewing "the exhibited" items, takes cognisance of the love story details. The museum needs to remain permanently open for love couples (the book is always accessible to those who read it) in order for the visitors to lose a sense of time what, in Pamuk's opinion, is the greatest comfort in life. Similar to his famous predecessors, Orhan Pamuk builds his fictional literary world, enriching it with a sophisticated oriental seal, a novel that genuinely connects the East cultural circles with Western ones.

\section{Methodical model: Orhan Pamuk, The Museum of Innocence}

The specific structure of a literature lesson based on the principles of problem based teaching is realised through several stages: creating a problem situation, recognising and defining the problem, solution seeking, individual pupils' work including the result analysis and correction, adopting the acceptable solution, and assigning new tasks. The order of the teaching stages and situations should be perceived in principle only in order to avoid the formalisation of the teaching process. By their preparation, the teacher would encompass the following determinants: main information about the teaching unit, threefold aims, time duration, place of teaching, teaching aids, and teaching methods. The planning of the teaching content includes the agreement on the selection of the literary template, reading (time limit) as well as the novel interpretation, individual tasks and creative expression.
Subject:
Croatian language
Grade:
$4^{\text {th }}$
Teaching unit:
Orhan Pamuk, "Museum of Innocence"
Type of lesson: novel interpretation
Number of lessons:
two double lessons (+ hours of individual work)

WORK CONTENT:

1. previous preparation and motivation (problem situation provoking)

2. defining the main problem and methods of work

3. problem solving / individual research

4. discussion on research results

5. creating a problem situation

6. research and announcement of results

7. creating a new problem situation (individual homework assignments) 
TEACHING AIMS:

\section{Literary aims:}

- to investigate a postmodern novel and its aesthetic value from the perspective of the problem perceived; to integrate oral and written discussion on a literary topic;

\section{Educational aims:}

- to develop positive moral character and analyze the term faithfulness; to nourish literary creativity and sensibility for belles-lettres (beautiful literature);

\section{Functional aims:}

- to train pupils for individual text interpretation and getting along in wider complexes of literary creativity; to develop the abilities of communication and written expression; to train pupils for the use of professional literature;

\section{TEACHING TECHNIQUES:}

- frontal and individual class work, pair work, and group work

\section{TEACHING METHODS:}

- correlation-integrative approach (history, geography, TV broadcast), method of heuristic conversation (with perspective and alternative questions), method of creative reading, logical methods of analysis and synthesis, reproductive-creative method, method of concretization in problem solving, etc.

\section{TEACHING TOOLS AND AIDS:}

- the literary work, a computer with a LCD projector, multimedia: Istanbul greeting cards and photographs of world-famous museums, a video interview with Orhan Pamuk, and an episode of the serial "1001 Nights";

\section{TEACHER ROLE:}

- the teacher is not in the centre of the teaching process but takes the role of the organizer of pupils' research activities; prepares individual work tasks that pupils would solve individually because the teaching unit is based on the logical-cognitive basis.

\section{LEVELS OF PROBLEM SOLVING:}

- the problem is primarily viewed at the ideological-topical level followed by the plot-compositional and linguistic-stylistic level;

\section{PLACE OF REALIZATION:}

- school library and Croatian language classroom

Literature (teachers):

- professional: Kovačević, M, Pripovijedanje i stvaralaštvo, "agregatna stanja" narativnog diskursa, Lodge, D., Načini modernog pisanja: metafora, metonimija $i$ tipologija moderne književnost, Lotman, J. M., Struktura umjetničkog teksta, and Pavličić, P., Poetika manirizma

- methodical: Bežen, A., Metodika, znanost o poučavanju nastavnog predmeta and Rosandić, D., Metodika književnoga odgoja.

Literature (pupils):

Pamuk, O., Muzej nevinosti, Solar, M., Teorija književnosti, and KošutićBrozović, N., Čitanka iz stranih književnosti II. 


\section{ARTICULATION OF THE INTERPRETATION LESSON}

\section{Previous preparation and motivation}

The announcement of the teaching unit: Orhan Pamuk, The Museum of Innocence ("Masumiyet Müzesi", 2008). The time of interpretation should be agreed upon in advance by both the teacher and pupils, and the aim of problem-based research should be defined: dealing with the problem of faithfulness, premarital relationships and innocence, providing the basic information about the writer as well. Pupils will receive the instructions on the elements important to be written in a reading diary. The introductory sequences of a Turkish serial "1001 Nights" can serve as motivation. The teacher can use a PowerPoint presentation to present the scanned title page of the novel.

\section{FIRST DOUBLE LESSON}

As for the introductory stage, pupils are being faced with the problem that needs to be solved since the unknown based on contradictions calls for a documented answer, i.e. thesis that is to be proven and defended. In order to provoke a problem situation and introductory discussion, the following quotation can be used: "The museum of innocence is a place where one lives with a dead person." 5 This is followed by the question whether pupils have been thinking about what problem should be investigated and discussed first. While expressing their attitudes, they conclude that the problem could be thet of a woman's position in a patriarchal environment and passion in a society where premarital relationships are a taboo.

\section{Defining the main problem and methods of work}

Despite his progressive European views, Kemal's philosophy of life is at the same time influenced by his environment. Therefore, pupils should discuss the writer's provocation of the conservative attitude to innocence since it is about the position of a girl in that society, and to single out the episodes where this problem is revealed completely. A problem question follows: Is Kemal a happy or unhappy man? Does he have a guilty conscience because of his infidelity?

\section{Problem solving / individual research}

Pupils will get 10 minutes to investigate the problem in the text individually or in a group (using their notes and reading diaries) and try to argue their attitudes. An oral

\footnotetext{
${ }^{5}$ The problem situation can also be created by a questionnaire: an orientation questionnaire consists of problem questions that demand from pupils to take their own attitude towards certain phenomena in the book. The questions become the starting point for the analysis: before the novel interpretation, pupils answer the questions that actualize ideas, moral or social problems, e.g. a) Why Kemal refuses the love of the member of his social class and passionately falls in love with poor Fusun?, b) Does Kemal approach life in the same way at the beginning and the end of the novel?, c) What events influence Kemal's changing?, d) Why does Fusun still return to Kemal?, etc. As the answers are not identical and unambiguous, they create an interesting problem situation.
} 
discussion will follow by which the whole class would try to single out relevant conclusions. As the problem solution is being realized within a certain context, we can view the act of the actual problems of faithfulness and guilt in Pamuk's novel in relation to Flaubert's novel Madame Bovary and compare the way in which the two writers present the topical problem.

\section{Discussion on research results}

The teacher encourages conversation by the following question: Do you think that the writer condemns Kemal or supports him? Argue your attitudes! The pupils who believe that Pamuk condemns Kemal may stress the unhappy story ending, while the ones who believe the opposite may claim that the author identifies himself with his protagonist. Next, the analysis of the protagonist's social status and its philosophy of life can follow. We aim at psychological character by raising the following question: Can we accept the claim that Kemal is an honest and mature man who takes the responsibility for his actions? In order to direct the course of discussion, we need some concise comments and quotations such as "He behaved like a child in a sweet shop, he swallowed sweets greedily all the time." The discussion is followed by the comparison of the protagonist's experience (notes possible on transparencies):

What do you feel about Kemal?
a) scorn
b) love
c) sympathy and understanding
Why?

By using the analytical search for proof and quoting parts of the text, pupils corroborate their opinions followed by the juxtaposition of attitudes. The social analysis of the historical conditions in the story and observation of social classes and their interrelationships may serve as the starting points for the discussion on character and characterization. ${ }^{6}$ A problem situation can be created by comparing two characters from two different novels (Kemal and Werther). A stimulating thesis is: Kemal is the Werther of the $21^{\text {st }}$ century. In order to prove the thesis, "Werther's" outpourings of emotions can be mentioned (emotional sensitivity, feeling of redundancy, spleen, etc.). As regards the characterization of Kemal's character (i.e. writer's alter ego), pupils get the task to support their opinion by the quotations from the novel. We next observe the way in which the writer constructs his female protagonist and whether he, viewing the world from " a male" perspective, succeeds to present a female subject authentically. The following questions may prove encouraging for ethical characterization: Explain how

${ }^{6}$ As regards the main character, we will consider the intertextual genealogy of the protagonist with the emphasis on psychological characterization. As for the meaning systems referring to a melancholic industrialist, one can problematize the rules of the affiliation to a social microstructure and principles of forming intimate acquaintances. During the character characterization, pupils will look into the questions of substantial content of Kemal's character and his emotional stratum as well as formal position among other characters. 
Fusun reveals herself in her statements., If Kemal is the postmodern Werther, is Fusun his Lotta? Pupils opt for the positive or negative variant and explain their opinions. The discussion on character characterization may be accompanied by a transparency display:

\title{
RELATIONSHIP BETWEEN MAIN CHARACTERS
}

\author{
love quadrilateral \\ (gentleness, friendship) Sibel \\ Kemal (passion, physical, desire to own) Fusun \\ (tolerance and business partnership) Feridun
}

\section{SECOND DOUBLE LESSON}

\section{Creating a problem situation}

The following question would encourage further conversation: In which way are erotic elements and pop culture manifested in Pamuk's novel? As regards the interpretation of erotica, an example of the author's direct addressing the reader should be offered: "If there are worried secondary school teachers...I can suggest them to skip this page. As regards the inquisitive Museum visitors, I beg them to view the exhibits and to know that what I have to do I primarily do for Fusun who is looking at me with her sad and frightened look." The popular elements are also in accordance with this, and therefore the influence of pop culture should be clarified as well (football derby, film world, trendy snobbery, and yellow journalism). Pupils' task is to discover the following motive links:

- girls analyse similarities to a Hollywood film (red dress, Chevrolet, dawn and plane tree in front of hotel Semiramida, feeble ending as in American melodramas);

- boys examine the position of football in Pamuk's novel - Kemal's visit to a Fenerbahçe match;

A new problem situation follows: Discover the way in which the writer (re)interprets the poetics of mannerism and romanticism! Each element should be corroborated with strongly argued examples from the novel.

Romanticistic elements:

- at the plot level: Goethe's love triangle and pain as a creative impulse;

- at the level of character characterization and the degree of tension between them (emotionality).

The analytical observation of the mannerist elements: Single out the stylistic procedures by which the writer detaches from the poetics of realistic narration and, by exaggerating consciously, also includes fantastic elements in his text (pictorial overview of internal organs, antique collector, dialogue between the writer and his character, the author's attitude to literary criticism, etc.). As for the interpretation, we can follow a specific inter-relation between classical and modern in the novel.

Postmodern elements are evident in three stylistic procedures:

a) ludistic playing with the reader's horizon of expectations

b) breaking the linear course of narration, and 
c) pronounced intertextuality and autoreferentiality.

Pupils' task is to corroborate the aforementioned characteristics by the quotations from the novel. Since Kemal talks about the museums of his much loved writers (Dostojevski, Nabokov, Proust, Tagore, Pirandello, Strindberg, Alan Poe, Flaubert), we can make comments about whether pupils recognize the peculiarities of Pamuk poetics in the other writers' works and how they are realized?

The final transparency notes follow: Could the love relationship between Kemal and Fusun have a happy ending and under what conditions?

a) if Kemal left Sibel earlier

b) if Fusun did not marry Feridun

c) if the society did not interfere in their relationship

d) some other possibility.

\section{Research and announcement of results}

Pupils opt for one of the offered possibilities or suggest their own assumptions. This is followed by the definition of problems and methods of work. The final thesis of the interpretation could be: Explain the symbolic meaning of the motives life and novel in "The Museum of Innocence"? In case there is no answer, pupils can be provided with the following schematic overview (transparency or PowerPoint): NOVEL /

/ if the world = illusion, and the novel = illusion as well, the deduction is LIFE = STORY /

$/$ if the book $=$ museum, and $a$ reader $=a$ visitor, the deduction is EXHIBIT $=$

Pupils' task is to find the fragments that support this problem, write down their observations, read them, and discuss them as well.

\section{FINAL PART OF THE LESSON}

\section{Creating a new problem situation / individual homework assignments}

As for the literary template and sources of information (literature) offered, pupils use valid arguments to pronounce the final judgement and solve the initial issue. They solve the problem task individually consulting literary criticism and literature, and give written reports on their results. As regards the next lesson, the teacher assigns a written discussion on the following topic: "Pamuk has taught us that human happiness is fragile and true love is sad". In order to solve the problem question more easily, pupils can use the handouts that contain a set of exercises for elaboration: What makes problematic characters literary interesting?, What does it mean to love?, Should a person be condemned for infidelity?, How would you define adultery?, How to justify the fulfilling of ideals through the prism of marital scandal?

A written discussion should include the following structure:

- hypothesis setting 


\author{
- hypothesis proving \\ - hypothesis confirmation or rejection.
}

It is important to inform pupils that they can use quotations in case they want to substantiate someone's thoughts by this person's own words, confirm their own attitude by other people's thoughts, use the author's words picturesquely or confirm the peculiarity of the author's style. Before the end of the lesson, pupils should also be informed of how their achievements would be evaluated and that the presentation of their individual work and its results would take place during the next lesson. At the end, we can watch a video interview with Orhan Pamuk, a part of an episode of the serial "1001 Nights" or listen to authentic Turkish music.

\title{
Conclusion
}

As regards the aforementioned methodical model of required reading interpretation, a problem situation is being created by raising problem questions and setting up problem tasks and hypotheses that are to be proven either by confirmation or rejection. In this connection, the key issues are strong arguments, confrontation of opinions, and quotations of authentic text where the problem is detected. By engaging complex intellectual functions while solving a certain problem, creative knowledge occurs. Affirming the method of research, pupils themselves raise problem questions and try to give answers by doing some research, i.e. reading the offered text and professional literature. As for setting up hypotheses, they discuss using literary critical judgements and create a problem solving plan. A polemical situation encourages the correction of the obtained results affirming thus the freedom of thinking and democracy of polemics. A free choice of required reading demands additional literary teacher's commitment: staying current with and reading topical literary hits, equipping school book supply by new titles, making efforts to present selected titles and motivate pupils for reading books which are not encompassed by the curriculum nor the system of required reading. Although demands for the extension of book supply may additionally burden schools limited financial means, educators must not disregard an essential prerequisite to a contemporary school - improvement of the quality of teaching. The teacher can offer titles according to their own choice, i.e. reading preference, what proves to be methodically justified and in accordance with the autonomy of syllabus planning. As regards the combining of methodical possibilities of entering the world of literary text, pupils are to be encouraged by a problem situation because only by the adventure of research would they reveal their reflective abilities (Gajić, 2004). Unknown problem situations and their solving activate in pupils not only operative but also creative knowledge. As for the literature domain, this dimension is obvious in a deep engagement of the symbolism and association with an artistic work. The teacher needs to stimulate the abilities aimed at gaining such knowledge in their pupils because thus the results of the educational process would be at a higher level as well. Regardless of the fact that teaching marked by problem solving is efficient, pupils also find it interesting because it activates their cognizance processes and stimulates them for individual work and application of gained knowledge as well as managing in new problem situations. A 
motivating combination of rational and emotion inspires a larger interest for an encounter with a new literary template and introduces pupils to the methods of scientific research, getting them used to applying the gained knowledge in practice. At the same time, problem based teaching provides larger pupil autonomy during the completion of single teaching units since they can set up problems and plan their solution by themselves. Qualify and willingly read popular titles, such as Pamuk's Museum of Innocence, can freshen secondary school literature teaching and empower aesthetic dialogue in the communication triangle further. Since the interaction between a reader and a literary work is one of the basic starting points of the teaching methodology of the Croatian language, teaching process managers, i.e. teachers, should definitely not disregard pupils' interests. Pamuk's popular cultural model may contribute to a stimulating environment in schools, resulting in a direct reduction of the disproportion between life and school, and positive influence on pupils achievements. In this context, a book would not become a dusty museum exhibit or an odious school task but exciting reading and source of intellectual pleasure. All we need to do is to look between its covers, in the right way, along with our pupils.

\section{Bibliography}

BEŽEN, A. (2008) Metodika, znanost o poučavanju nastavnog predmeta, Profil, Zagreb

Komunikacija u nastavi hrvatskoga jezika, ur. Marijana Češi i Mirela Barbaroša-Šikić, Naklada Slap, Zg, 2007, str. 156.

GAJIĆ, O. (2004), Problemska nastava književnosti u teoriji $i$ praksi. Rezultati eksperimentalnih istraživanja, Filozofski fakultet, Novi Sad

KARLOVIĆ, M. (2004) Izbor, čitanje i obrada lektire od četvrtog do osmog razreda osnovne škole (U: Napredak, vol. 145, br. 1, Zagreb, str. 27.-32.)

KINERT-BUČAN, D. (1983) Čitanje je život knjige, Naša knjiga, 5,

LAZZARICH, M. (2001) Interes srednjoškolskih učenika za sadržaje lektire (U: Život i škola, br. 6, Osijek, str.7.-16.)

LAZZARICH, M. (2004), Književnost valja približiti mladima (U: Napredak, vol. 145, br. 1, Zagreb, str. 83.-91.)

LOTMAN, J. M. (2001) Struktura umjetničkog teksta, Alfa, Zagreb

MIKIĆ, K. (2001) Medijska kultura i tehnička podrška, Zapis, PB, Zagreb

PLAVŠIĆ, M. i LJUBEŠIĆ, M. Književni interesi mladeži (na području Istarske i Primorskogoranske županije) (U: Metodički obzori 4 (2009) 1-2, Pula, str. 125.-141.)

PLEVNIK, D. (2006), Fortuna čitanja, Hrvatsko čitateljsko društvo, Osijek

SABOLOVIĆ-KRAJINA, D. (1989) Neki aspekti čitalačke kulture mladih (U: Vjesnik bibliotekara Hrvatske 32 (1-4), Zagreb, str. 71.-94.)

VLADILO, I. (2002) Lektira - radost čitanja ili tortura (U: Zbornik radova Proljetne škole školskih knjižničara, Novi Vinodolski, Ministarstvo prosvjete i športa Republike Hrvatske, Prva sušačka hrvatska gimnazija, Rijeka, str. 89.-94.)

Sources: Čaušević)

PAMUK, O. (2009) Muzej nevinosti, Vuković \& Runjić, Zagreb (prev. Karima Ferim i Ekrem

Odluka o popisu lektire za osnovnu školu i srednje škole, Prosvjetni vjesnik, godina III.,broj 5 
Zagreb, 22. svibnja 2001.

PENNAC, D. (1996), Od korica do korica, Irida, Zagreb

www.ala.org

www.aasla.org

Metodički obzori 6(2011)3

Prethodno priopćenje

UDK: 371.3:82]:373.5

Primljeno: 20. 10. 2010.

\title{
STVARALAČKI PRISTUP KNJIŽEVNOME DJELU U SUSTAVU PROBLEMSKE NASTAVE
}

\author{
dr.sc. Marinko Lazzarich \\ Učiteljski fakultet Sveučilišta u Rijeci \\ e-mail: mlazzari@inet.hr
}

\section{Sažetak}

Osnovni cilj školske lektire jest odgajanje čitateljske publike sposobne za estetsku komunikaciju s književnim djelom. Smatrajući kako sloboda izbora bitno određuje učenički odnos prema školskoj lektiri, autor teksta promišlja o učinkovitosti planiranja i realizacije postojećega programa. Interpretativni pristupi utemeljeni na načelima suvremenosti i komparativnosti u lektirnom sustavu Hrvatskoga jezika primjenjivi su kako u gimnazijskom tako i u programima srednjih strukovnih škola. Aktualna uspješnica Muzej nevinosti, turskoga nobelovca Orhana Pamuka, postaje predložak za propitivanje mogućnosti poticajne kombinacije izborne lektire $\mathrm{s}$ problemskim nastavnim sustavom. U tekstu se nudi model metodičke interpretacije romana u nastavi književnosti za četvrti razred srednje škole, sa ciljem jačanja analitičkih kompetencija mladih čitatelja. Suvremeni sustav problemske nastave omogućuje stvaralački pristup književnome djelu, stavljajući učenika u poziciju subjekta koji razvija svoju kreativnost i sposobnost kritičkoga mišljenja.

Ključne riječi: kultura čitanja, lektira, problemska nastava, literarna komunikacija, načelo suvremenosti, Orhan Pamuk, Muzej nevinosti 